\title{
A Cointegration of the Exchange Rate and Macroeconomic Fundamentals: The Case of the Indonesian Rupiah vis-á-vis Currencies of Primary Trade Partners
}

\author{
Agus Salim 1 and Kai Shi * (1) \\ School of Economics, Northeast Normal University, Changchun 130024, China; ags192@nenu.edu.cn \\ * Correspondence: shik142@nenu.edu.cn
}

Received: 28 February 2019; Accepted: 25 April 2019; Published: 13 May 2019

\begin{abstract}
Since the appearance of persistent research finding a disconnection between the exchange rate and its macroeconomic fundamentals, the empirical debate has not stopped. Studies employ various methods to explain the presence of the exchange rate disconnect puzzle, including applying models to the case of emerging market economies. However, the exchange rate has different determinants in some countries. To revisit this puzzle in an emerging market currency, we analyzed the cointegration of the exchange rate of the Indonesian Rupiah vis-á-vis currencies of primary trade partners and its macroeconomic fundamentals. The empirical results based on Autoregressive Distributed Lag (ARDL) and Nonlinear Autoregressive Distributed Lag (NARDL) models show that the fundamental variables consistently drive the exchange rate. The trade surplus as an extended nonlinear variable revealed high feedback to the exchange rate volatility in the long-run.
\end{abstract}

Keywords: cointegration; exchange rate disconnect puzzle; macroeconomic fundamentals; emerging market economies; NARDL; trade balance

\section{Introduction}

Interdependence in international finance affects the correlation of all macroeconomic variables according to several empirical studies, contrary to theoretical concepts. One of the empirical debates is the relationship between exchange rates and macroeconomic fundamentals. Theoretically, exchange rate volatility, in the long run, is determined by several macroeconomic fundamentals such as money supply, real income, real interest rates, inflation, trade balance, etc. (Abhyankar et al. 2005). Another piece of evidence that supports the relationship between exchange rates and fundamentals was provided by Charles and Darné (2009) and Laganà and Sgro (2007), who discussed theoretical developments and explanations. They also revealed econometric techniques, including increasing data and economic value by evaluating the performance of these fundamental models.

Since the introduction of exchange rate disconnect puzzles through empirical studies by Meese and Rogoff (1983), the investigation of the relationship between exchange rates and macroeconomic fundamentals continues. They used a sample of the exchange rates of three developed countries' currencies, namely US dollars against the German Mark, the Japanese Yen, and the British Pound. The macroeconomic variables included in their study are the difference in the money supply, the difference in output, the difference in inflation rates, the difference in interest rates, the US trade balance, and the foreign trade balance. They concluded that the structural model used in the study resulted in low significance. This finding presented a conundrum, which sparked a debate on the so-called "exchange rate disconnect puzzle" in international macroeconomics. 
Recently, the study of the relationship between the exchange rate and macroeconomic fundamentals has grown. Engel and West (2005) assessed the determinants of the exchange rate, confirming the existence of the puzzle. They employed the exchange rate of US dollars vis-á-vis the currencies of six industrialized countries: Canada, France, Germany, Italy, Japan, and the UK. The finding illustrates a small influence on some fundamental macroeconomic variables such as the money supply, outputs, inflation, and interest rates in predicting the movements of the floating exchange rates.

Engel and West's (2005) study on exchange rate determination has received considerable academic interest, especially for confirming the exchange rate disconnect puzzle. Bahmani-Oskooee et al. (2015) compared the model using data from the same country with the Autoregressive Distributed Lag (ARDL) model developed by Pesaran et al. (2001). They concluded that the results were the opposite of Engel and West (2005). Besides, they also supported the monetary model of exchange rate determination. Moreover, their results were also supported by Tawadros (2017), who also referred to the model of Engel and West (2005). By using another sample, namely the exchange rate between Australian dollars and five currencies of Australian trading partners, they concluded that there is a relationship between exchange rates and macroeconomic fundamentals. In addition, the fundamental variable "granger" causes the exchange rate.

All studies mentioned above analyze the case of the main currency being form developed countries. However, the study of the relationship between exchange rate and macroeconomic fundamentals in the case of an emerging market economy is also fascinating. AbuDalu and Ahmed (2014) used a sample of several developing countries in Southeast Asia, revealing a significant relationship between exchange rates and macroeconomic variables. Moreover, Ouyang and Rajan (2016) analyzed the real exchange rate determinants in 34 developing economies, although they focused on the effect of inflation targeting, while other macroeconomic variables were also included. The result show that macroeconomic variables affect the volatility of the real exchange rate, especially in developing Asian economies. Thus, a possible extension of study on the presence of the relationship between exchange rates and macroeconomic fundamentals is needed to analyze the case of an emerging market economy.

This study aimed to revisit the Meese-Rogoff exchange rate disconnect puzzle in Indonesia, a Next-11 emerging economy, one of the eleven countries that are expected to become the largest economies in the 21st century after Brazil, Russia, India, and China. As an emerging market economy in Southeast Asia, Indonesia has major trade relationships with several leading economies including China, the USA, Japan, the EU, and Singapore. These relations mean the Indonesian Rupiah is also exchanged with major currencies of those primary trade partner countries. We employed the previous model developed by Tawadros (2017) to examine the cointegration of the Indonesian Rupiah vis-á-vis the currencies of its five biggest trading partner countries, namely Chinese Yuan, United States Dollar, Japanese Yen, Euro, and Singaporean Dollar, and the macroeconomic fundamentals.

Evidence of cointegration between exchange rates and macroeconomic fundamentals in the case of the emerging economy was discovered. Since we employed the linear ARDL approach developed by Pesaran et al. (2001) and nonlinear ARDL by Shin et al. (2011), the results confirm a cointegration of all ten multivariate equations. This manuscript supports and expands the work of Evans and Lyons (2005), AbuDalu and Ahmed (2014), Bahmani-Oskooee et al. (2015), and Tawadros (2017). Moreover, a particular modified variable, i.e. trade balance, showed high statistical significance in both the short-run and the long-run. The remainder of this manuscript is organized as follows. Section 2 presents the previous study of the exchange rate and macroeconomic fundamentals relationship. Section 3 depicts the methodology and econometric modeling process. Section 4 analyzes the result of a causality test and discusses the possible exchange rate disconnect puzzle in the Indonesian Rupiah. Section 5 provides a brief conclusion.

\section{Literature Review}

After the collapse of the Bretton Woods System, a new system was created to avoid the speculation of the foreign exchange market. Laganà and Sgro (2007) explain that the destruction of the Bretton 
Woods System encouraged a test of the exchange rate model using the determination and causality of a theoretical variable. The empirical debates described in the introduction of this manuscript explained that the exchange rate is determined by a set of macroeconomic variables. Empirical results are also diversified in different countries through the level of economy. Most of the studies developed the determinants of an exchange rate model which focused on major currencies from developed countries. However, some previous studies also found the cointegration of exchange rate and macroeconomic fundamentals in the case of emerging market economies.

Gente and Leon-Ledesma (2006) analyzed the consequences of foreign interest rate changes on real exchange rate volatility in East Asian emerging countries. To obtain the equilibrium of the real exchange rate, they estimated the effect of the real interest rate, output, government expenditure, and dummy 1997 Asian crisis using Vector Autoregressive (VAR). The result shows a negative and significant effect of the US interest rate on the real exchange rate volatility for all of the countries, except Thailand. Domestic output confirms the positive and significant effect for three countries, except South Korea. The dummy crisis 1997 variable that was applied for Thailand, Malaysia, and South Korea has a positive and significant effect on the real exchange rate of these three countries' currencies against the US dollar.

Another cross-country study, Lee-Lee and Hui-Boon (2007) tested the volatility of foreign exchange market in Southeast Asian countries using a Vector Autoregressive (VAR) and ARDL approach in order to account the cointegration of exchange rate and macroeconomic fundamentals. The application of the procedure results in a long-run movement among the estimated variables. In the short-run, money supply and trade balance influence the volatility of the Malaysian Ringgit. Money supply and stocks have exerted pressure on the volatility of the Indonesian Rupiah, while the inflation rate influences the volatility of the Thai Baht. Moreover, a similar combination of macroeconomic variables in Indonesia manifest the volatility of the Singaporean Dollar. They concluded that, generally, the interest rate variable shows a small impact on the volatility of exchange rate in Southeast Asian countries.

A more recent analysis of the exchange rate causality by Sarno and Schmeling (2014) who attempted the validity test for macroeconomic fundamentals on exchange rates including the Indonesian Rupiah, the result shows that macroeconomic fundamentals such as the inflation rate, money supply, and nominal GDP, have strong significant predictive power to the exchange rate. They grouped a sample, in which G1 contains $25 \%$ of all countries that have depreciated to the US dollar whereas G4 contains $25 \%$ of all countries with the highest appreciation against the US dollar. They found that a highly significant number of G1 countries had the strongest experiences in depreciation against the US dollar when their inflation rate increased. Beyond the inflation rate, the variables of money supply and GDP growth differential had indicated a monotonic decline when the sample moved from G1 to G4 countries.

Bouraoui and Phisuthtiwatcharavong (2015) addressed the unresolved issue of the exchange rate model on the Thai Baht against the US dollar. They estimated monthly data used Ordinary Least Square (OLS) to explain the effect of macroeconomic fundamentals on the behavior of THB/USD nominal exchange rate. The result presents an influence of the term of trade and the international reserve to the exchange rate volatility. However, interest rate differential, manufacturing production index, monetary base, and government debt do not exhibit a significant relationship with the exchange rate. Correctly, the lower price of exporting goods in Thailand is responded to by depreciation of the THB/USD rate, while the increase of the international reserve shows an opposite effect.

To explore the issue of the break date effect on the exchange rate, Raza and Afshan (2017) revisited the structural break test to prove the cointegration of exchange rate and macroeconomic variables in Pakistan. They estimated the ARDL bound testing approach, the Johansen and Juselius cointegration approach, and the Gregory and Hansen structural break co-integration. They confirmed a significant relationship of a few considered variables in the long-run. In particular, the long-run estimation provided a positive and significant effect of the money supply and inflation rate. However, an increase 
in the terms of trade, trade openness, and economic growth has significantly depreciated the value of the Pakistani Rupee against the US dollar.

\section{Research Method}

\subsection{Data Source}

The data used for the following analysis includes quarterly data, from 1999: IV to 2017: I for China, USA, Japan, and a total of European Monetary Union, and from 2013: I to 2017: I for Singapore, as the availability of the data. The original dataset mainly obtained from the official site of the International Monetary Fund (IMF), the Organization for Economic Co-operation and Development (OECD), and the Indonesian Statistical Bureau. ${ }^{1}$ The dependent variable is the spot exchange rate of the Indonesian Rupiah vis-á-vis foreign currencies. The independent variables are differentiated from broad money using M2 of Indonesia and foreign countries, differential GDP growth between Indonesia and foreign countries, interest rate differential, consumer price index as a proxy of the inflation rate differential, and trade balance between Indonesia and each trade partner country. To ensure that the data are stationary, we applied a logarithmic form for all macroeconomic variables and exchange rate except for the interest rate and inflation rate (the description of measurement and source for each variable is explained in Appendix A).

\subsection{Empirical Model}

Since the main purpose of this study is to examine the primary relationship of the exchange rate and macroeconomic fundamentals in the form of flexible price monetary model of Frenkel (1976) and Bilson (1978) as well as sticky price monetary model of Dornbusch (1976) and Frankel (1979), we adapted the previous monetary model from the study of Tawadros (2017). We modified the model by including the trade balance variable as Meese and Rogoff (1983) and Obstfeld and Rogoff (2001) have described in order to represent the sticky-price asset model of Hooper and Morton (1982). The original model of this study is transformed into econometrics model as outlined by Equation (1):

$$
\log _{t}=\propto+\beta\left(\log \bar{m}_{t}-\log \bar{m}_{t}^{f}\right)-\varphi\left(\log y_{t}-\log y_{t}^{f}\right)+\gamma\left(i_{t}-i_{t}^{f}\right)+\eta\left(\pi_{t}-\pi_{t}^{f}\right)+\mu \log B_{t}+\varepsilon_{t},
$$

where $\log s_{t}$. represents the nominal exchange rate; the $\log \bar{m}_{t}-\log \bar{m}_{t}^{f}$ represents the ratio of Indonesia and foreign money supply differential and $\log y_{t}-\log y_{t}^{f}$ represents the ratio of Indonesia to the foreign output differential. The $i_{t}-i_{t}^{f}$ represents Indonesia and foreign interest rate differential and $\pi_{t}-\pi_{t}^{f}$ is the inflation rate differential. Since the result of Frankel (1979) found that $\gamma>0$, we expect $\eta>|\gamma|$. The $\log \mathrm{TB}_{\mathrm{t}}$ represents the trade balance between Indonesia and each trade partner country and $\varepsilon_{t}$ is the disturbance term.

Umit (2016) explained that Indonesian Rupiah is one of weak currency which have encountered to the global shock. It would appear a structural break effect to the exchange rate volatility. Thus, the stationary exchange rate series which contains structural changes should be tested. We addressed this issue by employing Lee-Straizicich unit root test with two breaks developed by Lee and Strazicich $(2001,2003)$. Two structural time breaks $\left(\mathrm{TB}_{1}\right.$ and $\left.\mathrm{TB}_{2}\right)$ are allowed to capture the structural change in the two break point which included two dummy variables, $\mathrm{DU}_{1}$ and $\mathrm{DU}_{2}$, respectively. As such the transformation of the original model with two dummy variables becomes:

$$
\begin{aligned}
\log _{\mathrm{t}}= & \propto+\beta\left(\log \overline{\mathrm{m}}_{\mathrm{t}}-\log \overline{\mathrm{m}}_{\mathrm{t}}^{\mathrm{f}}\right)-\varphi\left(\log \mathrm{y}_{\mathrm{t}}-\log \mathrm{y}_{\mathrm{t}}^{\mathrm{f}}\right)+\gamma\left(\mathrm{i}_{\mathrm{t}}-\mathrm{i}_{\mathrm{t}}^{\mathrm{f}}\right)+\eta\left(\pi_{\mathrm{t}}-\pi_{\mathrm{t}}^{\mathrm{f}}\right)+\mu \log \mathrm{TB}_{\mathrm{t}}+ \\
& \omega \mathrm{DU}_{1, \mathrm{t}}+\partial \mathrm{DU_{2, \textrm {t } }}+\varepsilon_{\mathrm{t}},
\end{aligned}
$$

1 All data can be shared under the request for further research. 
where $\mathrm{DU}_{1}$. takes the value of one if $\mathrm{t}>\mathrm{TB}_{1}$ and otherwise zero; and finally, $\mathrm{DU}_{2}$ takes the value of one if $\mathrm{t}>\mathrm{TB}_{2}$ and otherwise zero.

\subsubsection{Autoregressive Distributed Lag (ARDL) Model}

In order to obtain the cointegration of exchange rate and macroeconomic fundamentals, we have to transform Equation (2) into Autoregressive Distributed Lag (ARDL) model. The advantage of this approach is the applicability to either pure stationary variables, integrated process, or their mixture. Mainly, this estimation used the bound testing approach to test the cointegration which developed by Pesaran et al. (2001). The ARDL is also used by some empirical studies to see the effect of the validity of the monetary theories to exchange rate determination. In this manuscript, the ARDL model was used to analyze the existence of a cointegration relationship between the exchange rates and macroeconomic fundamental. Accordingly, we set up the ARDL model as follows:

$$
\begin{aligned}
\Delta \operatorname{Logs}_{\mathrm{t}}= & \alpha+\sum_{\mathrm{k}=1}^{\mathrm{n}_{1}} \varnothing_{\mathrm{k}} \Delta \log \mathrm{s}_{\mathrm{t}-\mathrm{k}}+\sum_{\mathrm{k}=0}^{\mathrm{n}_{2}} \beta_{\mathrm{k}} \Delta\left(\log \overline{\mathrm{m}}_{\mathrm{t}}-\log \overline{\mathrm{m}}_{\mathrm{t}}^{\mathrm{f}}\right)_{\mathrm{t}-\mathrm{k}}+\sum_{\mathrm{k}=0}^{\mathrm{n}_{3}} \varphi_{\mathrm{k}} \Delta\left(\log \mathrm{y}_{\mathrm{t}}-\log \mathrm{y}_{\mathrm{t}}^{\mathrm{f}}\right)_{\mathrm{t}-\mathrm{k}} \\
& +\sum_{\mathrm{k}=0}^{\mathrm{n}_{4}} \gamma_{\mathrm{k}} \Delta\left(\mathrm{i}_{\mathrm{t}}-\mathrm{i}_{\mathrm{t}}^{\mathrm{f}}\right)_{\mathrm{t}-\mathrm{k}}+\sum_{\mathrm{k}=0}^{\mathrm{n}_{5}} \eta_{\mathrm{k}} \Delta\left(\pi_{\mathrm{t}}-\pi_{\mathrm{t}}^{\mathrm{f}}\right)_{\mathrm{t}-\mathrm{k}}+\sum_{\mathrm{k}=0}^{\mathrm{n}_{6}} \mu_{\mathrm{k}} \Delta \operatorname{logTB} \mathrm{b}_{\mathrm{t}-\mathrm{k}} \\
& +\sum_{\mathrm{k}=0}^{\mathrm{n}_{7}} \omega_{\mathrm{k}} \Delta \mathrm{DU} \mathrm{U}_{1, \mathrm{t}-\mathrm{k}}+\sum_{\mathrm{k}=0}^{\mathrm{n}_{8}} \partial_{\mathrm{k}} \Delta \mathrm{DU}_{2, \mathrm{t}-\mathrm{k}}+\delta_{1} \mathrm{~s}_{\mathrm{t}-1}+\delta_{2}\left(\log \overline{\mathrm{m}}_{\mathrm{t}}-\log \overline{\mathrm{m}}_{\mathrm{t}}^{\mathrm{f}}\right)_{\mathrm{t}-1} \\
& +\delta_{3}\left(\log \mathrm{y}_{\mathrm{t}}-\log \mathrm{y}_{\mathrm{t}}^{\mathrm{f}}\right)_{\mathrm{t}-1}+\delta_{4}\left(\mathrm{i}_{\mathrm{t}}-\mathrm{i}_{\mathrm{t}}^{\mathrm{f}}\right)_{\mathrm{t}-1}+\delta_{5}\left(\pi_{\mathrm{t}}-\pi_{\mathrm{t}}^{\mathrm{f}}\right)_{\mathrm{t}-1}+\delta_{6} \operatorname{logTB} \mathrm{B}_{\mathrm{t}-1} \\
& +\delta_{7} D U_{1, \mathrm{t}-1}+\delta_{8} D U_{2, \mathrm{t}-1}+\varepsilon_{\mathrm{t}},
\end{aligned}
$$

Once the Equation (3) is estimated, the effects of each variable on the exchange rate in the short-run are inferred by the coefficient estimates attached to each of the first-differenced variables. The long-run effects are gained by estimating $\delta_{1}-\delta_{8}$ which are normalized by $\delta_{1}$. However, we applied an F-test to establish the existence of a long-run relationship which tested the null hypothesis of no cointegration. Pesaran et al. (2001) provide two sets of critical value in the stationary testing which applied inattentive of whether the variables are I(1) or I(0). An upper bound critical value assumes that all variables are $\mathrm{I}(1)$ and lower bound critical value assumes that for all variables are $\mathrm{I}(0)$. If the calculated F-statistic is above the upper bound, then all variables are jointly significant and indicated a long-run cointegration, respectively to the lower bound of calculated F-statistic.

On the other case, if the calculated F-statistic lies between these two bounds, the result is inconclusive, and we can use an alternative test by forming lagged error correction term of the linear combination of lagged level variables in Equation (3). The model is then re-estimated using the same number of optimum lags that are derived from the ARDL $\left(\mathrm{n}_{1}, \mathrm{n}_{2}, \mathrm{n}_{3}, \mathrm{n}_{4}, \mathrm{n}_{5}, \mathrm{n}_{6}, \mathrm{n}_{7}, \mathrm{n}_{8}\right)$ with the following equation:

$$
\begin{aligned}
\Delta \operatorname{Logs}_{\mathrm{t}}= & \alpha+\sum_{\mathrm{k}=1}^{\mathrm{n}_{1}} \varnothing_{\mathrm{k}} \Delta \log \mathrm{s}_{\mathrm{t}-\mathrm{k}}+\sum_{\mathrm{k}=0}^{\mathrm{n}_{2}} \beta_{\mathrm{k}} \Delta\left(\log \overline{\mathrm{m}}_{\mathrm{t}}-\log \overline{\mathrm{m}}_{\mathrm{t}}^{\mathrm{f}}\right)_{\mathrm{t}-\mathrm{k}}+\sum_{\mathrm{k}=0}^{\mathrm{n}_{3}} \varphi_{\mathrm{k}} \Delta\left(\log \mathrm{y}_{\mathrm{t}}-\log \mathrm{y}_{\mathrm{t}}^{\mathrm{f}}\right)_{\mathrm{t}-\mathrm{k}} \\
& +\sum_{\mathrm{k}=0}^{\mathrm{n}_{4}} \gamma_{\mathrm{k}} \Delta\left(\mathrm{i}_{\mathrm{t}}-\mathrm{i}_{\mathrm{t}}^{\mathrm{f}}\right)_{\mathrm{t}-\mathrm{k}}+\sum_{\mathrm{k}=0}^{\mathrm{n}_{5}} \eta_{\mathrm{k}} \Delta\left(\pi_{\mathrm{t}}-\pi_{\mathrm{t}}^{\mathrm{f}}\right)_{\mathrm{t}-\mathrm{k}}+\sum_{\mathrm{k}=0}^{\mathrm{n}_{6}} \mu_{\mathrm{k}} \Delta \log \mathrm{BB}_{\mathrm{t}-\mathrm{k}} \\
& +\sum_{\mathrm{k}=0}^{n_{7}} \omega_{\mathrm{k}} \Delta \mathrm{DU}_{1, \mathrm{t}-\mathrm{k}}+\sum_{\mathrm{k}=0}^{\mathrm{n}_{8}} \partial_{\mathrm{k}} \Delta \mathrm{DU}_{2, \mathrm{t}-\mathrm{k}}+\rho \mathrm{ECM}_{\mathrm{t}-1}+\varepsilon_{\mathrm{t}} .
\end{aligned}
$$

In this new specification, we also examined the direction and speed of adjustment in the short-run disequilibrium by estimating the sign and the significance of $\mathrm{ECM}_{\mathrm{t}-1}$ coefficient. Basically, the $\mathrm{ECM}_{\mathrm{t}-1}$ links the long-run equilibrium which is implied by the cointegration relationship, with the short-run adjustment process which the variables reacted to any shock in the long-run equilibrium. In the Equation (4) above, a negative and significant $\hat{\rho}_{i}$ indicates adjustment of the exchange rate toward the long-run equilibrium following any short-run disequilibrium. Finally, the higher absolute value of $\hat{\rho}_{i}$, the faster adjustment process or convergence rate. 


\subsubsection{Nonlinear Autoregressive Distributed Lag (NARDL) Model}

Equation (3) above has the primary assumption that trade balance has a symmetric effect on the dynamic of spot exchange rate of the Indonesian Rupiah vis-á-vis its five respective currencies. However, it would be possible that there is an asymmetric effect of the trade balance included in the model due to the fluctuation of export and import volume in Indonesia. If there are differences in the expectation of the changing variable over time, it is possible for the variable to have an asymmetric effect towards the dependent variable (Shin et al. 2011; Bahmani-Oskooee and Saha 2017). In order to test the effect of symmetric and asymmetric of trade balance towards spot exchange rate, we generated the trade balance to become two time-series variables. One variable represents a trade surplus, and the other one represents a trade deficit.

Shin et al. (2011) argued that the NARDL model is a flexible analysis model that was adopted from their technique and used in a wide range of economic phenomena. They developed a NARDL model that used an unemployment-output relationship and the Korean gasoline price case. They found a great confirmation that output growth has an asymmetric effect on the sensitivity of unemployment in the long run. Bahmani-Oskooee and Fariditavana (2015) have also run the effect of the exchange rate using the NARDL approach. They found an asymmetric effect of exchange rate on fluctuation of the trade balance. Moreover, Turan and Karakas (2018) employed the current account case and found that changes in the current account deficit have a significant effect on the budget deficit.

To address the symmetric and asymmetric effect of trade balance, we have to rewrite the change of $\log \mathrm{TB}$ variable as $\triangle \log \mathrm{TB}$. The $\Delta \log \mathrm{TB}$ variable includes positive and negative change based on the study of Turan and Karakas (2018). The positive changes represent a surplus in bilateral trading activities, and the negative changes represent a deficit in bilateral trading activities. We denote the positive changes by $\Delta \log \mathrm{TB}_{t}^{+}$and negative changes by $\Delta \log \mathrm{TB}_{\mathrm{t}}^{-}$. The denoted variables are then used to build the partial sum concept to generate the new variables with the following equations:

$$
\begin{aligned}
\operatorname{logTBPos}_{\mathrm{t}} & =\sum_{\mathrm{k}=1}^{\mathrm{n}} \Delta \log \mathrm{TB}_{\mathrm{t}}^{+}=\sum_{\mathrm{k}=1}^{\mathrm{n}} \max \left(\log \mathrm{TB}_{\mathrm{t}}, 0\right), \\
\log \mathrm{TBNeg}_{\mathrm{t}} & =\sum_{\mathrm{k}=1}^{\mathrm{n}} \Delta \log \mathrm{TB}_{\mathrm{t}}^{-}=\sum_{\mathrm{k}=1}^{\mathrm{n}} \min \left(\log \mathrm{TB}_{\mathrm{t}}, 0\right) .
\end{aligned}
$$

The $\log$ TBPos variable is the partial sum of positive change that represents the trade surplus, and the $\log$ TBNeg variable is the partial sum of adverse changes that represents the trade deficit. Then we replace $\log \mathrm{TB}$ variable of Equation (3) by $\log \mathrm{TBP}$ os and $\log \mathrm{TBNeg}$ to obtain the new equation as follows:

$$
\begin{aligned}
& \Delta \log _{\mathrm{t}}=\alpha+\sum_{\mathrm{k}=1}^{\mathrm{n}_{1}} \varnothing_{\mathrm{k}} \Delta \mathrm{s}_{\mathrm{t}-\mathrm{k}}+\sum_{\mathrm{k}=0}^{\mathrm{n}_{2}} \beta_{\mathrm{k}} \Delta\left(\log _{\mathrm{t}}-\log _{\mathrm{t}}^{\mathrm{f}}\right)_{\mathrm{t}-\mathrm{k}}+\sum_{\mathrm{k}=0}^{\mathrm{n}_{3}} \varphi_{\mathrm{k}} \Delta\left(\log _{\mathrm{t}}-\log _{\mathrm{t}}\right)_{\mathrm{t}-\mathrm{k}} \\
& +\sum_{\mathrm{k}=0}^{\mathrm{n}_{4}} \eta_{\mathrm{k}} \Delta\left(\mathrm{i}_{\mathrm{t}}-\mathrm{i}_{\mathrm{t}}^{\mathrm{f}}\right)_{\mathrm{t}-\mathrm{k}}+\sum_{\mathrm{k}=0}^{\mathrm{n}_{5}} \gamma_{\mathrm{k}} \Delta\left(\pi_{\mathrm{t}}-\pi_{\mathrm{t}}^{\mathrm{f}}\right)_{\mathrm{t}-\mathrm{k}}+\sum_{\mathrm{k}=0}^{\mathrm{n}_{6}} \mu_{\mathrm{k}} \Delta \operatorname{logTBPos}_{\mathrm{t}-\mathrm{k}} \\
& +\sum_{\mathrm{k}=0}^{\mathrm{n}_{7}} \sigma_{\mathrm{k}} \Delta \log \mathrm{BBNeg}_{\mathrm{t}-\mathrm{k}}+\sum_{\mathrm{k}=0}^{\mathrm{n}_{8}} \omega_{\mathrm{k}} \Delta \mathrm{DU}_{1, \mathrm{t}-\mathrm{k}}+\sum_{\mathrm{k}=0}^{\mathrm{n}_{9}} \partial_{\mathrm{k}} \Delta \mathrm{DU}_{2, \mathrm{t}-\mathrm{k}}+\delta_{1} \mathrm{~s}_{\mathrm{t}-1} \\
& +\delta_{2}\left(\log _{\mathrm{t}}-\log \mathrm{m}_{\mathrm{t}}^{\mathrm{f}}\right)_{\mathrm{t}-1}+\delta_{3}\left(\log \mathrm{y}_{\mathrm{t}}-\log \mathrm{y}_{\mathrm{t}}^{\mathrm{f}}\right)_{\mathrm{t}-1}+\delta_{4}\left(\pi_{\mathrm{t}}-\pi_{\mathrm{t}}^{\mathrm{f}}\right)_{\mathrm{t}-1}+\delta_{5}\left(\mathrm{i}_{\mathrm{t}}-\mathrm{i}_{\mathrm{t}}^{\mathrm{f}}\right)_{\mathrm{t}-1} \\
& +\delta_{6} \log _{\mathrm{TBPos}_{\mathrm{t}-1}}+\delta_{7} \log \mathrm{TBNeg}_{\mathrm{t}-1}+\delta_{8} \mathrm{DU}_{1, \mathrm{t}-1}+\delta_{9} \mathrm{DU}_{2, \mathrm{t}-1}+\varepsilon_{\mathrm{t}}
\end{aligned}
$$

The adjustment process of generating a partial sum variable above introduces a nonlinear in Equation (7) which so-called as nonlinear autoregressive distributed lag (NARDL), and the Equation (3) is linear ARDL model (Pesaran et al. 2001). The nonlinear ARDL could be estimated with the same procedure as used for estimating the linear ARDL model (Bahmani-Oskooee and Saha 2017). The symmetry and asymmetry effect of the trade balance will be defined by the result of coefficients and signs of $\triangle \mathrm{TBP}$ os and $\triangle \mathrm{TBNeg}$ variables. Furthermore, we used a standard Wald test which distributed 
as $\chi^{2}$ with one degree of freedom, to analyze short-run symmetric effect of trade balance with the null hypothesis $\mathrm{H}_{0}: \sum \mu=\sum \sigma$. Thus, the trade balance has a short-run asymmetry impact on the spot exchange rate when $\sum \mu \neq \sum \sigma$. For the long-run symmetric effect, the null hypothesis is $\mathrm{H}_{0}$ : $-\delta_{6} / \delta_{1}=-\delta_{7} / \delta_{1}$. If they are found to be the same, it indicates that the trade balance has a symmetry effect towards the spot exchange rate.

Finally, since we formed error correction term of the linear combination of variables in Equation (3), we also employed this term for the nonlinear model of Equation (7) and re-estimated using the same number of optimum lags derived from the $\operatorname{ARDL}\left(\mathrm{n}_{1}, \mathrm{n}_{2}, \mathrm{n}_{3}, \mathrm{n}_{4}, \mathrm{n}_{5}, \mathrm{n}_{6}, \mathrm{n}_{7}, \mathrm{n}_{8}, \mathrm{n}_{9}\right)$ as follows:

$$
\begin{aligned}
\Delta \operatorname{Logs}_{\mathrm{t}}= & \alpha+\sum_{\mathrm{k}=1}^{\mathrm{n}_{1}} \varnothing_{\mathrm{k}} \Delta \mathrm{s}_{\mathrm{t}-\mathrm{k}}+\sum_{\mathrm{k}=0}^{\mathrm{n}_{2}} \beta_{\mathrm{k}} \Delta\left(\log \mathrm{m}_{\mathrm{t}}-\log \mathrm{m}_{\mathrm{t}}^{\mathrm{f}}\right)_{\mathrm{t}-\mathrm{k}}+\sum_{\mathrm{k}=0}^{\mathrm{n}_{3}} \varphi_{\mathrm{k}} \Delta\left(\log \mathrm{y}_{\mathrm{t}}-\log \mathrm{y}_{\mathrm{t}}^{\mathrm{f}}\right)_{\mathrm{t}-\mathrm{k}} \\
& +\sum_{\mathrm{k}=0}^{\mathrm{n}_{4}} \eta_{\mathrm{k}} \Delta\left(\mathrm{i}_{\mathrm{t}}-\mathrm{i}_{\mathrm{t}}^{\mathrm{f}}\right)_{\mathrm{t}-\mathrm{k}}+\sum_{\mathrm{k}=0}^{n_{5}} \gamma_{\mathrm{k}} \Delta\left(\pi_{\mathrm{t}}-\pi_{\mathrm{t}}^{\mathrm{f}}\right)_{\mathrm{t}-\mathrm{k}}+\sum_{\mathrm{k}=0}^{\mathrm{n}_{6}} \mu_{\mathrm{k}} \Delta \log \operatorname{lBPos}_{\mathrm{t}-\mathrm{k}} \\
& +\sum_{\mathrm{k}=0}^{\mathrm{n}_{7}} \sigma_{\mathrm{k}} \Delta \log \operatorname{lBN}_{\mathrm{t}-\mathrm{k}}+\sum_{\mathrm{k}=0}^{\mathrm{n}_{8}} \omega_{\mathrm{k}} \Delta \mathrm{DU}_{1, \mathrm{t}-\mathrm{k}}+\sum_{\mathrm{k}=0}^{\mathrm{n}_{9}} \partial_{\mathrm{k}} \Delta \mathrm{DU}_{2, \mathrm{t}-\mathrm{k}}+\rho \mathrm{ECM}_{\mathrm{t}-1}+\varepsilon_{\mathrm{t}} .
\end{aligned}
$$

\section{Result and Discussion}

\subsection{Data Stationary Test Result}

To ensure the data used were either stationery at level or first differences, we employed stationarity tests. The result of the tests revealed that integrated in order variables are either I(0) or I(1). To analyze the stationary of the data, this study used unit root tests namely Augmented Dickey-Fuller (ADF) developed by Dickey and Fuller (1979) and Kwiatkowski-Phillips Schmidt-Shin (KPSS) developed by Kwiatkowski et al. (1992). However, their test so far does not provide a structural break in the data generating process of the variable assessed. To fill the gap of this criticism, we applied the Lee-Straizicich (LS) unit roots test developed by Lee and Strazicich $(2001,2003)$.

The result of the unit root test is presented in Table 1. Due to the rule of the stationary test, the probability of the t-statistic should be lower than $1 \%, 5 \%$, and $10 \%$ significance levels. The result of the ADF test showed that the log of spot exchange rates and differential money supply variables for all of the currency pairs were not stationary at the level, while the KPSS test showed inversely. However, all of the currency pairs are stationary at first difference by rejecting the null hypothesis at $10 \%$. In particular, since the test conducted under first differences, it can be concluded that there are no unit roots, and so all of the series are either I(0) or I(1). These results are in line with Tawadros (2017) who criticized the failure finding of Cushman (2000) and Engel and West (2005) in the detecting of a long-run relationship between the exchange rate and macroeconomic fundamental variables.

We employed ADF and KPSS tests, however, these tests did not allow a structural break during the stationary test process. To criticize this methodological phenomenon, we employed the Lee-Strazicich unit root test. The result is also presented in Table 1, and the required test for the two endogenous structural breaks which were identified earlier are also included. The break model rejects the null hypothesis of the existence of a unit root under the structural breaks for relative money supply, output differential, and trade balance, for the IDR vis-á-vis CNY and JPY. For the IDR vis-á-vis USD, the break model rejects the null hypothesis for all macroeconomic variables. However, for the IDR vis-á-vis EUR, the break model rejects the null hypothesis for the spot exchange rate, relative output, and interest rate, while for the IDR vis-á-vis SGD, the break model rejects the null hypothesis for the relative money supply, output differential, and trade balance. 
Table 1. Unit Root Testing Result.

\begin{tabular}{|c|c|c|c|c|}
\hline \multirow{2}{*}{ Variable } & \multirow{2}{*}{$\mathrm{ADF}$} & \multirow{2}{*}{ KPSS } & \multicolumn{2}{|c|}{ Lee-Strazicich Test (Break Model) } \\
\hline & & & T-Stat & ТВ \\
\hline & & R vis-á-vis CNY & & \\
\hline $\log _{t}$ & $-1.063[1]$ & $0.825^{* * *}[6]$ & $-4.626[7]$ & 2008Q1, 2012Q4 \\
\hline$\left(\operatorname{Logm}_{t}-\log _{t}^{f}\right)$ & $-0.407[1]$ & $0.926^{* * *}[5]$ & $-5.055[5]$ & 2008Q3, 2013Q4 \\
\hline$\left(\log y_{t}-\log y_{t}^{f}\right)^{\prime}$ & $-1.882[1]$ & $0.701^{* *}[5]$ & $-6.650 * 0^{* *}[5]$ & 2006Q2, 2008Q2 \\
\hline$\left(i_{t}-i_{t}^{f}\right)$ & $-3.478^{* *}[1]$ & $0.595^{* *}[5]$ & $-5.362[3]$ & 2009Q2, 2013Q2 \\
\hline$\left(\pi_{t}-\pi_{t}^{f}\right)$ & $-2.966^{* *}[1]$ & $0.287[5]$ & $-6.593 * *[6]$ & 2005Q2, 2011Q3 \\
\hline$\left(\log \mathrm{TB}_{\mathrm{t}}\right)$ & $-1.396[1]$ & $0.755^{* * *}[6]$ & $-18.009^{* * *}[1]$ & 2006Q4, 2008Q1 \\
\hline$\Delta \log S_{t}$ & $-5.432 * * *[1]$ & $0.093[0]$ & $-6.657 * *[5]$ & 2008Q2, 2011Q1 \\
\hline$\Delta\left(\log _{t}-\log _{t} f\right)$ & $-4.963^{* * *}[0]$ & $0.187[0]$ & $-6.492 * *[2]$ & 2008Q2, 2010Q1 \\
\hline$\Delta\left(\log y_{t}-\log y_{t}^{f}\right)$ & $-7.217^{* * *}[0]$ & $0.170[8]$ & $-8.439^{* * *}[6]$ & 2008Q2, 2011Q1 \\
\hline$\Delta\left(\mathrm{i}_{\mathrm{t}}-\mathrm{i}_{\mathrm{t}}^{\mathrm{f}}\right)$ & $-4.197^{* * *}[0]$ & $0.147[3]$ & $-5.505[8]$ & 2007Q1, 2010Q4 \\
\hline$\Delta\left(\pi_{t}-\pi_{t}^{f}\right)$ & $-5.132 * * *[3]$ & $0.043[3]$ & $-8.794^{* * *}[7]$ & 2005Q2, 2007Q3 \\
\hline$\Delta\left(\log \mathrm{TB}_{\mathrm{t}}\right)$ & $-4.781^{* * *}[0]$ & $0.108[2]$ & $-12.866^{* * *}[5]$ & 2007Q1, 2008Q1 \\
\hline & & R vis-á-vis USD & & \\
\hline $\log _{t}$ & $-0.490[2]$ & $0.602 * *[6]$ & $-4.814[5]$ & 2009Q2, 2013Q1 \\
\hline$\left(\operatorname{Logm}_{t}-\log _{t}^{f}\right)$ & $-2.929 * *[0]$ & $0.397 *[5]$ & $-7.092 * * *[3]$ & 2007Q2, 2010Q3 \\
\hline$\left(\log _{t}-\log y_{t}^{f}\right)^{\prime}$ & $-6.612 * * *[0]$ & $0.113[4]$ & $-7.703^{* * *}[4]$ & 2008Q2, 2009Q2 \\
\hline$\left(\mathrm{i}_{\mathrm{t}}-\mathrm{i}_{\mathrm{t}}^{\mathrm{f}}\right)$ & $-3.842 * * *[1]$ & $0.138[5]$ & $-5.888 *[3]$ & 2005Q3, 2008Q2 \\
\hline$\left(\pi_{t}-\pi_{t}^{f}\right)$ & $-2.938^{* *}[0]$ & $0.220[4]$ & $-6.018 *[7]$ & 2005Q2, 2011Q4 \\
\hline$\left(\log \mathrm{TB}_{\mathrm{t}}\right)$ & $-2.112[9]$ & $0.847^{* * *}[6]$ & $-8.893^{* * *}[8]$ & 2008Q3, 2010Q2 \\
\hline$\Delta \log S_{t}$ & $-5.818^{* * *}[1]$ & $0.141[2]$ & $-7.126^{* *}[1]$ & 2008Q1, 2009Q1 \\
\hline$\Delta\left(\log _{t}-\log _{t} f_{t}^{f}\right)$ & $-6.868^{* * *}[3]$ & $0.144[4]$ & $-7.948^{* * *}[3]$ & 2010Q2, 2011Q4 \\
\hline$\Delta\left(\log y_{t}-\log y_{t}^{f}\right)$ & $-11.573^{* * *}[0]$ & $0.189[22]$ & $-8.577^{* * *}[7]$ & 2008Q4, 2011Q2 \\
\hline$\Delta\left(\mathrm{i}_{\mathrm{t}}-\mathrm{i}_{\mathrm{t}}^{\mathrm{f}}\right)$ & $-3.499 * *[0]$ & $0.159[4]$ & $-5.846 *[3]$ & 2008Q2, 2010Q3 \\
\hline$\Delta\left(\pi_{t}-\pi_{t}^{f}\right)$ & $-5.929^{* * *}[3]$ & $0.037[0]$ & $-9.077^{* * *}[3]$ & 2005Q2, 2007Q2 \\
\hline$\Delta\left(\log \mathrm{TB}_{\mathrm{t}}\right)$ & $-2.284 *[8]$ & $0.153[3]$ & $-7.266^{* * *}[3]$ & 2007Q3, 2010Q3 \\
\hline & & DR vis-á-vis JPY & & \\
\hline $\log _{t}$ & $-1.338[2]$ & $0.933^{* * *}[5]$ & $-5.447[1]$ & 2006Q2, 2009Q2 \\
\hline$\left(\operatorname{Logm}_{t}-\log _{t}^{f}\right)$ & $2.213[1]$ & $0.895^{* * *}[6]$ & $-5.544[2]$ & 2005Q4, 2011Q2 \\
\hline$\left(\log y_{t}-\log y_{t}^{f}\right)^{\prime}$ & $-6.612^{* * *}[0]$ & $0.1123[4]$ & $-7.703^{* * *}[4]$ & 2008Q2, 2009Q2 \\
\hline$\left(i_{t}-i_{t}^{f}\right)$ & $-3.787^{* * *}[1]$ & $0.758^{* * *}[5]$ & $-5.759[5]$ & 2005Q2, 2012Q2 \\
\hline$\left(\pi_{t}-\pi_{t}^{f}\right)$ & $-2.656 *[0]$ & $0.562 * *[5]$ & $-9.894^{* * *}[8]$ & 2005Q2, 2007Q2 \\
\hline$\left(\operatorname{LogTB}_{t}\right)$ & $-2.115[1]$ & $0.351 *[5]$ & $-9.683^{* * *}[8]$ & 2008Q3, 2011Q3 \\
\hline$\Delta \log _{\mathrm{t}}$. & $-7.320^{* * *}[1]$ & $0.066[8]$ & $-8.229^{* * *}[1]$ & 2008Q2, 2009Q3 \\
\hline$\Delta\left(\operatorname{Logm}_{t}-\log _{t}^{f}\right)$ & $-3.132 * *[0]$ & $0.809^{* * *}[5]$ & $-5.655[7]$ & 2008Q2, 2011Q1 \\
\hline$\Delta\left(\log _{t}-\log _{t} y_{t}^{f}\right)$ & $-11.573^{* * *}[0]$ & $0.189[22]$ & $-8.577^{* * *}[7]$ & 2008Q4, 2011Q2 \\
\hline$\Delta\left(\mathrm{i}_{\mathrm{t}}-\mathrm{i}_{\mathrm{t}}^{\mathrm{f}}\right)$ & $-3.480 *[0]$ & $0.122[3]$ & $-6.254^{* *}[8]$ & 2010Q3, 2013Q4 \\
\hline$\Delta\left(\pi_{t}-\pi_{t}^{f}\right)$ & $-5.987^{* * *}[3]$ & $0.030[1]$ & $-7.783^{* * *}[8]$ & 2005Q2, 2007Q2 \\
\hline$\Delta\left(\operatorname{LogTB}_{t}\right)$ & $-3.846^{* * *}[0]$ & $0.392 *[4]$ & $-7.852^{* * *}[3]$ & 2007Q3, 2010Q3 \\
\hline & & R vis-á-vis EUR & & \\
\hline $\log _{t}$. & $-2.176[1]$ & $0.699^{* *}[5]$ & $-5.983 *[7]$ & 2009Q3, 2013Q1 \\
\hline$\left(\log _{t}-\log _{t}^{f}\right)$ & $0.111[1]$ & $0.893^{* * *}[6]$ & $-5.402[7]$ & 2007Q2, 2012Q3 \\
\hline$\left(\log y_{t}-\log y_{t}^{f}\right)^{f}$. & $-4.624^{* * *}[0]$ & $0.141[4]$ & $-8.480^{* * *}[7]$ & 2008Q2, 2013Q4 \\
\hline$\left(i_{t}-i_{t}^{f}\right)$. & $-5.152 * * *[1]$ & 0.149 [5] & $-6.271 *[1]$ & 2009Q2, 2012Q4 \\
\hline$\left(\pi_{t}-\pi_{t}^{f}\right)$. & $-2.639 *[0]$ & $0.211[5]$ & $-5.043[3]$ & 2006Q2, 2013Q2 \\
\hline$\left(\operatorname{LogTB}_{t}\right)$ & $-2.347[9]$ & $0.665^{* *}[6]$ & $-5.376[5]$ & 2008Q2, 2010Q4 \\
\hline$\Delta \operatorname{LogS}_{\mathrm{t}}$ & $-5.129^{* * *}[0]$ & $0.150[3]$ & $-6.034 *[1]$ & 2008Q4, 2013Q4 \\
\hline$\Delta\left(\log _{t}-\log _{t}^{f}\right)$ & $-3.771^{* * *}[0]$ & $0.370^{* *}[5]$ & $-6.9422 * * *[1]$ & 2005Q4, 2010Q3 \\
\hline$\Delta\left(\log y_{t}-\log y_{t}^{f}\right)$ & $-10.554^{* * *}[0]$ & 0.327 [37] & $-10.318^{* * *}[8]$ & 2008Q1, 2012Q1 \\
\hline$\Delta\left(\mathrm{i}_{\mathrm{t}}-\mathrm{i}_{\mathrm{t}}^{\mathrm{f}}\right)$ & $-4.529^{* * *}[1]$ & $0.106[3]$ & $-6.771^{* * *}[6]$ & 2005Q2, 2007Q4 \\
\hline$\Delta\left(\pi_{t}-\pi_{t}^{f}\right)$ & $-5.491^{* * *}[3]$ & $0.036[2]$ & $-9.314^{* * *}[3]$ & 2005Q2, 2007Q2 \\
\hline$\Delta\left(\log \mathrm{TB}_{\mathrm{t}}\right)$ & $-1.398 *[8]$ & $0.368^{* *}[4]$ & $-7.062^{* * *}[3]$ & 2008Q3, 2011Q1 \\
\hline
\end{tabular}


Table 1. Cont.

\begin{tabular}{ccccc}
\hline \multirow{2}{*}{ Variable } & \multirow{2}{*}{ ADF } & KPSS & \multicolumn{2}{c}{ Lee-Strazicich Test (Break Model) } \\
\cline { 3 - 5 } & & & T-Stat & TB \\
\hline & $-0.578[0]$ & IDR vis-á-vis SGD & & \\
\hline $\operatorname{LogS}_{\mathrm{t}}$ & $0.871^{* * *}[6]$ & $-5.104196[7]$ & 2008Q3, 2013Q1 \\
$\left(\operatorname{Logm}_{\mathrm{t}}-\right.$ Logm $\left._{\mathrm{t}}^{\mathrm{f}}\right)$ & $-2.278[4]$ & $0.413^{*}[4]$ & $-6.623^{* *}[8]$ & 2009Q3, 2014Q3 \\
$\left(\operatorname{Logy}_{\mathrm{t}}-\operatorname{Logy}_{\mathrm{t}}^{\mathrm{f}}\right)$ & $-1.713[9]$ & $0.302[4]$ & $-6.336^{* *}[7]$ & 2007Q3, 2009Q2 \\
$\left(\mathrm{i}_{\mathrm{t}}-\mathrm{i}_{\mathrm{t}}^{\mathrm{f}}\right)$ & $-3.254^{* *}[1]$ & $0.859^{* * *}[5]$ & $-5.730[5]$ & 2005Q2, 2011Q1 \\
$\left(\pi_{\mathrm{t}}-\pi_{\mathrm{t}}^{\mathrm{f}}\right)$ & $-2.339[0]$ & $0.302[5]$ & $-5.286[6]$ & 2005Q2, 2011Q4 \\
$\left(\operatorname{LogTB}_{\mathrm{t}}\right)$ & $-1.879[9]$ & $0.697^{* *}[6]$ & $-6.191^{* *}[8]$ & 2008Q2, 2011Q3 \\
$\Delta \operatorname{LogS}_{\mathrm{t}}$ & $-5.762^{* * *}[0]$ & $0.067[0]$ & $-6.879^{* * *}[1]$ & 2008Q1, 2009Q1 \\
$\Delta\left(\operatorname{Logm}_{\mathrm{t}}-\operatorname{Logm}_{\mathrm{t}}^{\mathrm{f}}\right)$ & $-6.142^{* * *}[3]$ & $0.046[2]$ & $-7.232^{* * *}[3]$ & 2006Q3, 2008Q3 \\
$\Delta\left(\operatorname{Logy}_{\mathrm{t}}-\operatorname{Logy}_{\mathrm{t}}^{\mathrm{f}}\right)$ & $-5.249^{* * *}[7]$ & $0.039[3]$ & $-6.387^{* *}[7]$ & 2005Q2, 2006Q4 \\
$\Delta\left(\mathrm{i}_{\mathrm{t}}-\mathrm{i}_{\mathrm{t}}^{\mathrm{f}}\right)$ & $-3.561^{* * *}[0]$ & $0.114[3]$ & $-6.296^{* *}[8]$ & 2010Q3, 2013Q4 \\
$\Delta\left(\pi_{\mathrm{t}}-\pi_{\mathrm{t}}^{\mathrm{f}}\right)$ & $-4.540^{* *}[3]$ & $0.063[4]$ & $-8.228^{* * *}[3]$ & 2005Q2, 2007Q3 \\
$\Delta\left(\operatorname{LogTB}_{\mathrm{t}}\right)$ & $-1.328^{*}[8]$ & $0.333[4]$ & $-6.826^{* * *}[7]$ & 2006Q4, 2007Q3 \\
\hline
\end{tabular}

The asterisk symbols showed the rejection of the null hypothesis at ${ }^{* * *}=1 \%,{ }^{* *}=5 \%$, and ${ }^{*}=10 \%$ (Source: Author's Computation Using E-views 10).

\subsection{The Analysis of Exchange Rate Determination Model}

Exchange rates determination of the Indonesian Rupiahs (IDR) vis-á-vis Chinese Yuan (CNY), United States Dollar (USD), Japanese Yen (JPY), Euro (EUR), and Singapore Dollar (SGD) as transaction currency used among these trading partner countries mainly estimated using autoregressive distributed lag (ARDL). In order to compare the result of the ARDL model, we used the new extension of the ARDL model, the nonlinear autoregressive distributed lag (NARDL). The result of both estimations is discussed in the preceding section.

\subsubsection{The Cointegration Analysis under the Linear ARDL Model}

The cointegration of the Indonesian Rupiah (IDR) vis-á-vis currencies of primary trade partner countries, and macroeconomic fundamentals were mainly estimated through ARDL. We followed Bahmani-Oskooee et al. (2015) and Tawadros (2017) who examined the multivariate model between the exchange rate and macroeconomic fundamentals separately. The assessed null hypothesis that there is no correlation between the spot exchange rate and macroeconomic fundamentals are examined in accordance of the study of Devereux and Engel (2002). The estimation for each model used a maximum of four lags with Schwarz Info Criterion (SIC) model selection method. Panopoulou and Pittis (2004) argued that SIC worked better than another selection method.

The result of the bounds testing under the linear ARDL model is presented in Table 2 with the assumption that all of the macroeconomic fundamentals are diversified linearly. Panel (A) shows the short-run estimates of the ARDL model, including the F-statistic test and the adjusted $\mathrm{R}^{2}$. Panel (A) also followed the diagnostic test for serial correlation, histogram normality, heteroskedasticity, and Ramsey-RESET for a functional form. The result of diagnostic test for each currency pair is well specified, with each equation having passed every test at a 5 percent level. Moreover, the adjusted $R^{2}$ shows that each estimation has a reasonable fit with the model, with the currency pair of the IDR vis-á-vis SGD having the highest goodness of fit. Finally, all the result of the error correction term that explains how long it takes for the system to revert to the equilibrium is negative and significant at 1 percent. It indicates that each model has a lower than 66.3 percent of the deviation in the short-run equilibrium which is corrected in a year.

The long-run estimated coefficients of the multivariate equation for each currency pairs is presented in panel (B). The result reveals a long-run equilibrium relationship between the exchange rate and macroeconomic fundamentals by rejecting the null hypothesis of no cointegration base on the existence of f-statistics of multivariate equations for each estimated currency pairs. This result refutes the previous study of Engel and West (2005) where all of their variables showed a small explanation to the 
floating exchange rate. However, it supports the study of Bahmani-Oskooee et al. (2015), Tawadros (2017). It is associated with the affirmation of money supply variable of Raza and Afshan's (2017) argument that an excess money supply cut down the interest rate by making money easier to acquire and devaluated the value of the home currency.

Moreover, the supply of money causes the availability of funds for buying goods and services. An increase in domestic money supply will depreciate the value of IDR vis-á-vis the CNY, USD, JPY, and SGD. However, in this study it has increased the value of IDR vis-á-vis the EUR. This finding has also confirmed the study of Lee-Lee and Hui-Boon (2007) who have reported a significant effect of money supply on the exchange rate movement in several Asian emerging economies.

The differential in output variable has no significant effect for the currency pair of the IDR vis-á-vis the USD and JPY. However, the value of other currency pairs namely the IDR vis-á-vis the CNY, EUR, and SGD have been affected by the movement of the relative output variable. In the case of a negative sign for the IDR vis-á-vis CNY and EUR, an increase in domestic output has reduced the value of IDR/CNY and IDR/EUR. This result had confirmed the study of Sarno and Schmeling (2014) who revealed a monotonic decline of the economic path when the exchange rate moved to the appreciation side (there is a moving phenomenon from G1 to G4 group countries).

Notably, the requirement of $\eta>|\gamma|$ as postulated by (Frankel 1979) cannot be met since the coefficient for the differential inflation rate is lower than the absolute value of the differential interest rate for each currency pair. In addition, the inflation rate differential provides a significant value at 1 percent for the IDR vis-á-vis the USD and SGD. This result confirmed that an increase of inflation rate in Indonesia depreciated the value of IDR/USD and IDR/SGD and was consistent with the study of Bilson (1978) and AbuDalu and Ahmed (2014) who provided the empirical result that the inflation differential and exchange rates have a positive correlation. However, this finding differs from Fitzgerald (2004), who stated that exchange rate volatility does not feedback to inflation since an increase in the interest rate in Indonesia caused by a tight monetary policy will attract a greater capital inflow, which will then appreciate the currency.

Likewise, the long-run coefficient of trade balance between Indonesia and its five biggest trading partner countries is strongly significant at 1 percent level to determine the exchange rate linearly. Although the study of Dekle et al. (2005) and Berman et al. (2012) used firm-level data, they showed a similar relationship between exchange rates and domestic export volume. The high depreciation as attached to the value of the spot rate especially to the exchange rates of IDR vis-á-vis the USD, EUR, and SGD, have correlated to the trading scenario in Indonesia with the United States, European countries, and Singapore. Respectively, China and Japan are the first and third largest trade partners of Indonesia, hence the finding of highly significant relationships is not very surprising. Following the previous big empirical finding, however, this result denies the explanation of Obstfeld and Rogoff (2001) about the international trade variable, they argued that the most traded goods market are not fully integrated into the exchange rates caused by the trade costs.

\subsubsection{The Cointegration Analysis under the Nonlinear ARDL Model}

Since the linear ARDL approach assumes that the trade balance is correlated with the spot exchange rate linearly, we modified this variable to become nonlinear. Following Shin et al. (2011), we estimated the Equation (7) of nonlinear ARDL by employing the same technique used in the linear ARDL model.

Table 3 presents the result of the bounds testing approach under the nonlinear ARDL model. The result of short-run estimates, as well as the diagnostic test, are presented in panel (A). The diagnostic test indicated that the model is quite stable, which there is no serial correlation among macroeconomic variables for each currency pair, except the IDR vis-á-vis CNY. It is proven by the F-statistic of Breusch-Godfrey Serial Correlation LM test. The Breusch-Pagan-Godfrey test for Heteroskedasticity, Ramsey-RESET for stability test, and the Jacque-Bera normality test report statistically significant F-statistics for each currency pair at a 5 percent significance level. Thus, the results indicated that each currency pair passed the diagnostic test for normality, heteroskedasticity, and the functional form. 
Table 2. Result of Bounds Testing Approach under the Linear ARDL Model.

\begin{tabular}{|c|c|c|c|c|c|}
\hline Variable & IDR vis-á-vis $\mathrm{CNY}$ & IDR vis-á-vis USD & IDR vis-á-vis JPY & IDR vis-á-vis EUR & IDR vis-á-vis SGD \\
\hline \multicolumn{6}{|c|}{ Panel A. Short-run Estimates } \\
\hline$\Delta\left(\log _{t}-\log m_{t}^{f}\right)$ & $0.001(0.002)$ & $0.003^{* *}(0.001)$ & $0.053^{* *}(0.026)$ & $0.001(0.002)$ & $0.00(0.001)$ \\
\hline$\Delta\left(\log _{\mathrm{t}-1}-\log \mathrm{m}_{\mathrm{t}-1}^{\mathrm{f}}\right)$ & & & & $-0.004 *(0.002)$ & $0.003^{* * *}(0.001)$ \\
\hline$\Delta\left(\log y_{t}-\log y_{t}^{f}\right)$ & $0.001(0.003)$ & $0.007(0.005)$ & $-0.427(0.897)$ & $-0.037(1.645)$ & $0.002 * * *(0.001)$ \\
\hline$\Delta\left(\log y_{t-1}-\log y_{t-1}^{f}\right)$ & $0.013^{* * *}(0.003)$ & $-0.008^{* *}(0.004)$ & & $4.441^{* *}(2.044)$ & \\
\hline$\Delta\left(\log y_{t-2}-\log y_{t-2}^{f}\right)$ & $0.011^{* * *}(0.003)$ & & & & \\
\hline$\Delta\left(\log y_{t-3}-\log y_{t-3}^{f}\right)$. & $0.005^{* *}(0.002)$ & & & & \\
\hline$\Delta\left(\mathrm{i}_{\mathrm{t}}-\mathrm{i}_{\mathrm{t}}^{\mathrm{f}}\right)$ & $0.023^{* * *}(0.005)$ & $0.046^{* * *}(0.012)$ & $-0.158(0.588)$ & $0.013 *(0.008)$ & $-0.038^{* * *}(0.010)$ \\
\hline$\Delta\left(\mathrm{i}_{\mathrm{t}-1}-\mathrm{i}_{\mathrm{t}-1}^{\mathrm{f}}\right)$ & & $-0.082^{* * *}(0.022)$ & & $0.001(0.010)$ & $-0.033^{* * *}(0.010)$ \\
\hline$\Delta\left(\mathrm{i}_{\mathrm{t}-2}-\mathrm{i}_{\mathrm{t}-2}^{\mathrm{f}}\right)$ & & $0.046^{* * *}(0.013)$ & & $-0.016^{* *}(0.006)$ & \\
\hline$\Delta\left(\pi_{\mathrm{t}}-\pi_{\mathrm{t}}^{\mathrm{f}}\right)^{\mathrm{\prime}}$ & $-0.007^{* * *}(0.001)$ & $-0.001(0.002)$ & $-0.043(0.164)$ & $0.002(0.003)$ & $0.006^{* * *}(0.002)$ \\
\hline$\Delta\left(\pi_{\mathrm{t}-1}-\pi_{\mathrm{t}-1}^{\mathrm{f}}\right)$ & $0.007^{* * *}(0.001)$ & & & $-0.010 *(0.005)$ & $0.005^{* * *}(0.001)$ \\
\hline$\Delta\left(\pi_{\mathrm{t}-2}-\pi_{\mathrm{t}-2}^{\mathrm{f}}\right)$ & $0.010^{* * *}(0.001)$ & & & $0.007 *(0.004)$ & $0.005^{* * *}(0.001)$ \\
\hline$\Delta\left(\pi_{\mathrm{t}-3}-\pi_{\mathrm{t}-3}^{\mathrm{f}}\right)$ & $0.007^{* * *}(0.002)$ & & & & \\
\hline$\Delta \log \mathrm{TB}_{\mathrm{t}}$ & $0.033^{* * *}(0.005)$ & $-0.226^{* * *}(0.098)$ & $4.042 * * *(0.929)$ & $0.659^{* * *}(0.197)$ & $0.133 * *(0.060)$ \\
\hline$\Delta \log \mathrm{TB}_{\mathrm{t}-1}$ & $-0.071^{* * *}(0.016)$ & $0.335^{* * *}(0.092)$ & & $0.946^{* * *}(0.263)$ & $0.178^{* * *}(0.042)$ \\
\hline $\mathrm{DU}_{1, \mathrm{t}}$ & $0.039(0.069)$ & $-0.079 * * *(0.025)$ & $-3.069^{* *}(1.402)$ & $0.013(0.025)$ & $0.143^{* * *}(0.022)$ \\
\hline $\mathrm{DU}_{1, \mathrm{t}-1}$ & $-0.831^{* * *}(0.156)$ & & $34.180^{* * *}(2.517)$ & $-0.093^{* * *}(0.026)$ & $0.079 * *(0.038)$ \\
\hline $\mathrm{DU}_{1, \mathrm{t}-2}$ & $-0.143 * * *(0.021)$ & & $-22.839^{* * *}(3.930)$ & & $-0.024(0.027)$ \\
\hline $\mathrm{DU}_{1, \mathrm{t}-3}$ & & & $-13.348 *(7.521)$ & & $-0.104^{* * *}(0.027)$ \\
\hline $\mathrm{DU}_{1, \mathrm{t}-4}$ & & & $21.705^{* * *}(3.855)$ & & \\
\hline $\mathrm{DU}_{2, \mathrm{t}}$ & $0.030 * *(0.016)$ & $0.066^{* * *}(0.020)$ & $-9.943^{* * *}(2.957)$ & $0.050^{* *}(0.020)$ & $0.005(0.014)$ \\
\hline $\mathrm{DU}_{2, \mathrm{t}-1}$ & $-0.120^{* * *}(0.020)$ & & & $0.076^{* * *}(0.014)$ & $0.019 * *(0.009)$ \\
\hline $\mathrm{DU}_{2, \mathrm{t}-2}$ & $-0.065^{* * *}(0.018)$ & & & $0.071^{* * *}(0.014)$ & $0.091^{* * *}(0.019)$ \\
\hline $\mathrm{Ecm}_{\mathrm{t}-1}$ & $-0.024^{* * *}(0.02)$ & $-0.119^{* * *}(0.021)$ & $-0.426^{* * *}(0.090)$ & $-0.370 * * *(0.034)$ & $-0.663^{* * *}(0.050)$ \\
\hline F-Statistic & $14.843^{* * *}$ & $3.597^{* *}$ & $2.407^{* *}$ & $11.481^{* * *}$ & $14.371^{* * *}$ \\
\hline Adjusted $R^{2}$ & 0.922 & 0.971 & 0.942 & 0.973 & 0.999 \\
\hline Serial Correlation & $2.405^{* * *}[0.1136]$ & $1.480^{* * *}[0.2397]$ & $2.679^{* *}[0.0816]$ & $3.012 * *[0.0681]$ & $2.893 * *[0.0800]$ \\
\hline Normality & $0.244^{* * *}[0.8850]$ & $0.341^{* * *}[0.8434]$ & $1.640^{* * *}[0.4405]$ & $0.563^{* * *}[0.7545]$ & $1.475^{* * *}[0.4782]$ \\
\hline Heteroskedasticity & $1.256^{* * *}[0.2902]$ & $1.277^{* * *}[0.2674]$ & $1.156^{* * *}[0.3457]$ & $0.572^{* * *}[0.9206]$ & $1.116^{* * *}[0.4030]$ \\
\hline Functional Form & $0.114^{* * *}[0.7392]$ & $1.980^{* * *}[0.1668]$ & $4.048^{* *}[0.0512]$ & $0.479^{* * *}[0.4953]$ & $1.390^{* * *}[0.2523]$ \\
\hline
\end{tabular}


Table 2. Cont.

\begin{tabular}{|c|c|c|c|c|c|}
\hline Variable & IDR vis-á-vis $\mathrm{CNY}$ & IDR vis-á-vis USD & IDR vis-á-vis JPY & IDR vis-á-vis EUR & IDR vis-á-vis SGD \\
\hline \multicolumn{6}{|c|}{ Panel B. Long-run Estimates } \\
\hline$\left(\log _{t}-\log _{t}^{f}\right)$ & $0.406^{* *}(0.196)$ & $0.024^{* *}(0.011)$ & $0.125^{* * *}(0.043)$ & $-0.012 * *(0.005)$ & $0.005^{* *}(0.002)$ \\
\hline$\left(\log y_{t}-\log y_{t}^{f}\right)^{\prime}$ & $-0.442 *(0.231)$ & $-0.002(0.054)$ & $-1.001(2.231)$ & $-1.157^{* * *}(0.271)$ & $0.003^{* * *}(0.001)$ \\
\hline$\left(i_{t}-i_{t}^{f}\right)$ & $-0.625(0.411)$ & $0.082^{* * *}(0.021)$ & $-0.370(1.459)$ & $-0.005(0.024)$ & $-0.087^{* * *}(0.006)$ \\
\hline$\left(\pi_{\mathrm{t}}-\pi_{\mathrm{t}}^{\mathrm{f}}\right)$ & $-0.547^{* *}(0.207)$ & $-0.012(0.018)$ & $-0.102(0.386)$ & $-0.002(0.008)$ & $0.030 * * *(0.004)$ \\
\hline $\operatorname{LogTB}_{t}$ & $1.422 * * *(0.474)$ & $0.915^{* * *}(0.030)$ & $9.485^{* * *}(1.938)$ & $0.749^{* * *}(0.055)$ & $0.263^{* * *}(0.025)$ \\
\hline $\mathrm{DU}_{1, \mathrm{t}}$ & $20.431^{* * *}(6.562)$ & $-0.670^{* * *}(0.186)$ & $39.019 * * *(6.540)$ & $-0.217^{* * *}(0.072)$ & $0.026(0.029)$ \\
\hline $\mathrm{DU}_{2, \mathrm{t}}$ & $6.261^{* * *}(2.153)$ & $0.556^{* * *}(0.156)$ & $-23.33^{* * *}(6.480)$ & $0.394^{* * *}(0.099)$ & $0.174^{* * *}(0.014)$ \\
\hline
\end{tabular}

Figures reported on the parenthesis ( ) are the standard error. An asterisk ${ }^{* * *}, * *$, and * indicates rejection of the null hypothesis at 1,5 , and 10 percent of significance level respectively (Source: Author's Computation Using E-views 10).

Table 3. The Result of Bounds Testing Approach under the Nonlinear ARDL Model.

\begin{tabular}{|c|c|c|c|c|c|}
\hline Variable & IDR vis-á-vis CNY & IDR vis-á-vis USD & IDR vis-á-vis JPY & IDR vis-á-vis EUR & IDR vis-á-vis SGD \\
\hline \multicolumn{6}{|c|}{ Panel A. Short-run Estimates } \\
\hline$\Delta\left(\log _{t}-\log _{t}^{f}\right)$ & $0.009^{* * *}(0.002)$ & $0.004^{* *}(0.001)$ & $-0.500 * * *(0.136)$ & $0.004(0.002)$ & $-0.001(0.001)$ \\
\hline$\Delta\left(\log _{t-1}-\log m_{t-1}^{f}\right)$ & $0.007^{* *}(0.002)$ & & & $-0.003(0.002)$ & $0.001(0.001)$ \\
\hline$\Delta\left(\log _{t-1}-\log m_{t-2}^{f}\right)$ & $0.005 *(0.002)$ & & & $0.008^{* * *}(0.002)$ & $0.003^{* * *}(0.001)$ \\
\hline$\Delta\left(\log y_{t}-\log y_{t}^{f}\right)$ & $-0.025^{* * *}(0.005)$ & $0.005(0.005)$ & $0.565(0.636)$ & $1.257 *(0.676)$ & $0.006^{* *}(0.002)$ \\
\hline$\Delta\left(\log y_{t-1}-\log y_{t-1}^{f}\right)$ & & $-0.009(0.006)$ & & & \\
\hline$\Delta\left(\mathrm{i}_{\mathrm{t}}-\mathrm{i}_{\mathrm{t}}^{\mathrm{f}}\right)$ & $0.083^{* * *}(0.008)$ & $0.046^{* * *}(0.013)$ & $1.736(1.895)$ & $0.028^{* * *}(0.007)$ & $-0.065^{* *}(0.024)$ \\
\hline$\Delta\left(\mathrm{i}_{\mathrm{t}-1}-\mathrm{i}_{\mathrm{t}-1}^{\mathrm{f}}\right)$ & $0.012(0.008)$ & $-0.082^{* * *}(0.0257)$ & $-2.308(1.693)$ & $-0.043^{* * *}(0.012)$ & $-0.038^{* * *}(0.009)$ \\
\hline$\Delta\left(\mathrm{i}_{\mathrm{t}-2}-\mathrm{i}_{\mathrm{t}-2}^{\mathrm{f}}\right)$ & $0.018 *(0.009)$ & $0.052^{* * *}(0.015)$ & & & \\
\hline$\Delta\left(\mathrm{i}_{\mathrm{t}-3}-\mathrm{i}_{\mathrm{t}-3}^{\mathrm{f}}\right)$ & $0.048^{* * *}(0.009)$ & & & & \\
\hline$\Delta\left(\pi_{t}-\pi_{t}^{f}\right)$ & $-0.025^{* * *}(0.003)$ & $-0.002(0.002)$ & $-0.641^{* *}(0.25)$ & $-0.007 *(0.004)$ & $0.013 * *(0.005)$ \\
\hline$\Delta\left(\pi_{\mathrm{t}-1}-\pi_{\mathrm{t}-1}^{\mathrm{f}}\right)$ & $0.020^{* * *}(0.003)$ & & & $0.003(0.003)$ & $0.010^{* *}(0.003)$ \\
\hline$\Delta\left(\pi_{\mathrm{t}-2}-\pi_{\mathrm{t}-2}^{\mathrm{f}}\right)$ & $0.025^{* * *}(0.003)$ & & & $0.001(0.001)$ & $0.013^{* * *}(0.002)$ \\
\hline$\Delta\left(\pi_{\mathrm{t}-3}-\pi_{\mathrm{t}-3}^{\mathrm{f}}\right)$ & $0.019 * * *(0.003)$ & & & $-0.011^{* * *}(0.002)$ & \\
\hline$\Delta \log \mathrm{TBPos}_{\mathrm{t}}$ & $-0.064 *(0.032)$ & $-0.186 *(0.109)$ & $26.484^{* * *}(7.261)$ & $0.737^{* * *}(0.149)$ & $0.100(0.111)$ \\
\hline$\Delta \log \operatorname{TBPos}_{\mathrm{t}-1}$ & $-0.219^{* * *}(0.039)$ & $0.326^{* * *}(0.097)$ & & $0.539 *(0.271)$ & $-0.287^{* *}(0.100)$ \\
\hline
\end{tabular}


Table 3. Cont.

\begin{tabular}{|c|c|c|c|c|c|}
\hline Variable & IDR vis-á-vis CNY & IDR vis-á-vis USD & IDR vis-á-vis JPY & IDR vis-á-vis EUR & IDR vis-á-vis SGD \\
\hline \multicolumn{6}{|c|}{ Panel A. Short-run Estimates } \\
\hline$\Delta \log \mathrm{TBPos}_{\mathrm{t}-2}$ & $-0.154^{* * *}(0.034)$ & & & $-1.676^{* * *}(0.351)$ & \\
\hline$\Delta \log \mathrm{TBNeg}_{\mathrm{t}}$ & $0.047^{* * *}(0.006)$ & $-0.269(0.170)$ & $-55.65^{* * *}(15.34)$ & $0.286 *(0.157)$ & $0.035(0.100)$ \\
\hline$\Delta \log$ TBNeg $_{\mathrm{t}-1}$ & $-0.004 *(0.002)$ & $0.767^{* * *}(0.258)$ & & $-1.415^{* * *}(0.178)$ & $-0.099(0.129)$ \\
\hline$\Delta \log _{\text {TBNeg }}{ }_{t-2}$ & & $-0.755^{* * *}(0.194)$ & & & $0.349 *(0.157)$ \\
\hline $\mathrm{DU}_{1, \mathrm{t}}$ & $0.500 * * *(0.088)$ & $-0.206^{* * *}(0.0381)$ & $-1.793(1.658)$ & $-0.228^{* * *}(0.060)$ & $0.190 * * *(0.038)$ \\
\hline $\mathrm{DU}_{1, \mathrm{t}-1}$ & & & $27.082^{* * *}(2.344)$ & $-0.070(0.431)$ & $0.061(0.038)$ \\
\hline $\mathrm{DU}_{1, \mathrm{t}-2}$ & & & $-38.099 * * *(4.003)$ & $-0.201^{* * *}(0.024)$ & $0.170 * *(0.070)$ \\
\hline $\mathrm{DU}_{2, \mathrm{t}}$ & $0.023(0.018)$ & $-0.003(0.015)$ & $-8.598 *(4.509)$ & $0.049^{* * *}(0.012)$ & $-0.018(0.009)$ \\
\hline $\mathrm{DU}_{2, \mathrm{t}-1}$ & $-0.085^{* * *}(0.022)$ & $0.072^{* * *}(0.008)$ & & $0.072 * * *(0.010)$ & $-0.010(0.019)$ \\
\hline $\mathrm{DU}_{2, \mathrm{t}-2}$ & $-0.005(0.021)$ & $0.008(0.004)$ & & $0.091^{* * *}(0.024)$ & $0.037 *(0.018)$ \\
\hline $\mathrm{DU}_{2, \mathrm{t}-3}$ & $0.103^{* * *}(0.020)$ & $-0.086^{* * *}(0.010)$ & & & \\
\hline $\mathrm{Ecm}_{\mathrm{t}-1}$ & $-0.041^{* * *}(0.005)$ & $-0.021^{* * *}(0.004)$ & $-0.241^{* * *}(0.050)$ & $-0.516^{* * *}(0.029)$ & $-0.896^{* * *}(0.059)$ \\
\hline F-Statistic & $6.153^{* * *}$ & $2.788^{* * *}$ & $2.130 * * *$ & $20.066^{* * *}$ & $10.031^{* * *}$ \\
\hline Adjusted $\mathrm{R}^{2}$ & 0.919 & 0.980 & 0.947 & 0.995 & 0.999 \\
\hline Serial Correlation & $13.679(0.0000)$ & $0.096^{* * *}(0.9086)$ & $0.752^{* * *}[0.4785]$ & $3.002 * * *[0.1003]$ & $3.968^{* * *}[0.0929]$ \\
\hline Normality & $10.958^{* *}(0.004)$ & $0.690 * * *(0.7084)$ & $2.359 * * *[0.3074]$ & $7.707^{* *}[0.0212]$ & $2.078^{* * *}[0.3538]$ \\
\hline Heteroskedasticity & $1.554^{* * *}(0.1560)$ & $1.706^{* *}(0.0863)$ & $1.041^{* * *}[0.4364]$ & $0.568^{* * *}[0.9003]$ & $0.627^{* * *}[0.8379]$ \\
\hline Functional Form & $3.914 * *(0.061)$ & $3.656 * *(0.0641)$ & $1.202^{* * *}[0.2797]$ & $5.662 * *[0.0386]$ & $1.881^{* * *}[0.2193]$ \\
\hline Wald S & $4.133^{* *}$ & $16.489^{* * *}$ & $14.381^{* * *}$ & 3.601 * & $6.003^{* *}$ \\
\hline Wald L & $14.538^{* * *}$ & $3.134 *$ & $9.446^{* * *}$ & $3.614^{*}$ & $3.004 *$ \\
\hline \multicolumn{6}{|c|}{ Panel B. Long-run Estimates } \\
\hline$\left(\log _{t}-\log _{t}^{f}\right)$ & $0.059(0.045)$ & $0.171^{* *}(0.084)$ & $-2.077^{* * *}(0.702)$ & $0.037^{* * *}(0.009)$ & $-0.004(0.003)$ \\
\hline$\left(\log y_{t}-\log _{t} y_{t}^{f}\right.$ & $-0.802^{* * *}(0.225)$ & $-0.190(0.301)$ & $2.349(2.857)$ & $-3.923^{* * *}(0.056)$ & $0.005^{* *}(0.002)$ \\
\hline$\left(i_{t}-i_{t}^{f}\right)$ & $-1.159^{* * *}(0.313)$ & $0.766^{* * *}(0.073)$ & $-2.379(3.472)$ & $0.037^{* * *}(0.009)$ & $-0.121^{* * *}(0.012)$ \\
\hline$\left(\pi_{t}-\pi_{t}^{f}\right)$ & $0.793^{* * *}(0.086)$ & $-0.108(0.114)$ & $-2.666^{* * *}(0.925)$ & $-0.034^{* * *}(0.007)$ & $0.050^{* * *}(0.007)$ \\
\hline $\operatorname{LogTBPos}_{t}$ & $2.198^{* * *}(0.509)$ & $6.720 * * *(1.634)$ & $90.107^{* * *}(6.198)$ & $0.977^{* * *}(0.056)$ & $0.261^{* * *}(0.028)$ \\
\hline $\operatorname{LogTBNeg}_{t}$ & $1.055^{* * *}(0.337)$ & $-12.321 * *(5.510)$ & $-98.375^{* * *}(7.027)$ & $-2.295^{* * *}(0.329)$ & $0.388^{* * *}(0.053)$ \\
\hline $\mathrm{DU}_{1, \mathrm{t}}$ & $12.276^{* * *}(4.024)$ & $-9.870^{* * *}(2.212)$ & $-53.26^{* * *}(21.598)$ & $-1.196^{* * *}(0.149)$ & $0.166^{* * *}(0.041)$ \\
\hline $\mathrm{DU}_{2, \mathrm{t}}$ & $3.308^{* * *}(0.859)$ & $-0.415 *(0.739)$ & $-35.746 *(18.238)$ & $0.410^{* * *}(0.042)$ & $0.132^{* * *}(0.024)$ \\
\hline
\end{tabular}

Figures reported on the parenthesis ( ) are the standard error. An asterisk ${ }^{* * * * *}$, and ${ }^{*}$ indicates rejection of the null hypothesis at 1,5 , and 10 percent of significance level respectively (Source: Author's Computation Using E-views 10). 
Additionally, the Adjusted $\mathrm{R}^{2}$ explains that the multivariate equation for each currency pair has a good fit, with the IDR vis-á-vis SGD has the best fit. The panel (A) also reported that all the result of the error correction term is negative and significant at 1 percent. The coefficients of $\mathrm{Ecm}_{\mathrm{t}-1}$ indicated that each model has less than 89.6 percent of the deviation in the short-run equilibrium, which is corrected in a year. Furthermore, the Wald test rejects the null hypothesis of $\mathrm{H}_{0}: \sum \mu=\sum \sigma$. It implied that in the short-run, the sum of the coefficient $\Delta \log$ TBPos is significantly different to the sum of the coefficient $\triangle \log$ TBNeg. Finally, the result of the Wald-L test reflects an evidence of long-run asymmetric effect of the trade balance.

Panel (B) of Table 3 presents the result of long-run estimates under the nonlinear ARDL. The result of F-statistic affirms the existence of cointegration between the exchange rate and macroeconomic fundamentals, hence rejecting the null hypothesis of no cointegration. The trade balance is then modified to become trade surplus and trade deficit due to the nonlinear ARDL model. The estimates of Equation (7) present an existence of asymmetry long-run impact on the spot exchange rate. Since we found that the coefficient of trade surplus and trade deficit in the $\delta_{6} \neq \delta_{7}$ requirement been met, this supports the result of the long-run Wald test.

Compared to the linear ARDL for the IDR vis-á-vis CNY, the nonlinear ARDL for this currency pair has a higher cointegration, where most of the macroeconomic variables are significant at 1 percent. The modified variable, namely trade surplus and trade deficit, have a high significance for each currency pairs at 1 percent, except the trade deficit for IDR vis-á-vis the USD, which is significant at 5 percent. The positive significance of the trade surplus variable indicates that an improvement in the trade surplus between Indonesia and the trade partner countries lead to higher export revenue, increases the higher demand of the currency and boost the value of the Indonesian rupiah vis-á-vis the five currencies of the trading partner countries.

The coefficient of the trade deficit variable for the IDR vis-á-vis CNY and SGD showed a similar sign of the trade surplus variable. Following the fact of the trade deficit between Indonesia and China, the positive value of the spot exchange rate of IDR vis-á-vis CNY showed the higher trade deficit of goods and services towards China. The finding of the negatively significant of trade deficit entirely differs from the study of Chowdhury (1993) and Dekle et al. (2005). By using another level of data, they explained that the reduction of export volume correlates with an appreciation in the exchange rate. The deficit of trade balance has been responded by the increased of the value of the IDR/USD, IDR/JPY, and IDR/EUR.

Finally, the effect of the global shock to the exchange rate volatility between Indonesian rupiah vis-á-vis the currencies of trade partner countries are statistically significant. The implementation of dummy structural break for each currency pair successfully confirms the previous study of Tawadros (2017), who criticized the explanations of Cushman (2000) and Engel and West (2005) as failing to present a cointegration between the exchange rate and macroeconomic fundamentals. In Table 1, most of the structural break date correspond to the global crisis in 2008. The result of this study statistically confirms the significant effect of the first dummy variable $\left(D_{1}\right)$ as the most appropriate term reflecting when the crisis happened, rather than second dummy variable $\left(\mathrm{DU}_{2}\right)$ which represented the extended period of global shock.

\section{Conclusions}

The study of the relationship between exchange rate and macroeconomic fundamentals have matured in some developed economies. The innovations are widened to explore the exchange rate determinants such as analysis, statistical reform, and especially some theoretical variables. The study of this phenomenon has also implemented in several emerging economies, with the conclusion of cointegration between the exchange rate and the considered macroeconomic fundamentals. This study employed the currency of Indonesia vis-á-vis the five most significant trading partner currencies in order to prove the presence of cointegration in an emerging economy. The analysis compared the new econometric technique to prove the relationship of the exchange rate and macroeconomic 
fundamentals whether these economic variables are connected or disconnected. The result of the ARDL test showed that there is a high correlation between the exchange rate and its fundamental variables, both in the short-run and the long-run for each currency pair. Moreover, all five multivariate equations explain that almost all of the fundamental variables serve as a pass through to the exchange rates volatility. The modified variable, the trade balance, presents as the most statistically significant. Overall, in the long-run, the linear ARDL model produces twenty-one significances over twenty-eight fundamental variables.

The development of ARDL is also used to compare the result by including the asymmetric effect of the trade surplus and trade deficit in the nonlinear ARDL estimation. The trade balance including both the surplus and the deficit are significant for each currency pair. However, the trade deficit variable for the IDR vis-á-vis the CNY and SGD is negatively significant. The implementation of the dummy structural break has profoundly responded by the volatility of the exchange rate. Overall, the nonlinear manner provides a higher cointegration which has thirty-four significances over forty fundamental variables for determining the exchange rate of the IDR vis-á-vis the five currencies of trade partner countries in the long-run.

Author Contributions: Conceptualization, A.S. and K.S.; Methodology, A.S. and K.S.; Software, A.S.; Writing-Original Draft Preparation, A.S.; Writing-Review and Editing, A.S.; and Supervision, K.S.

Funding: This research was financially supported by the Ministry of Education Humanities \& Social Science Fund under Grant No. 15YJC790086; Jilin Scientific Development Plan under Grant No. 20150418048FG and Jilin Education Department the 12th Five-year Plan Social Science Research Project 2015-555; National Social Scientific Funds 18VSJ045; and Fundamental Scientific Research Funds of Central University subordinate to the Ministry of Education.

Conflicts of Interest: The authors declare no conflict of interest.

\section{Appendix A}

The explanation of the data used to carry out the estimation is described as follows:

The spot exchange rate of the Indonesian rupiah, Chinese Yuan, Japanese Yen, Euro, and

$=$ Singapore dollar (in terms of current US dollar). The data come from the official site of the International Financial Statistic of IMF;

$\overline{\mathrm{m}}_{\mathrm{t}}-\quad$ Money supply differential is the difference between M2 in Indonesia and foreign countries (in

$\frac{\mathrm{m}_{\mathrm{t}}-}{\overline{\mathrm{m}}_{\mathrm{t}}^{\mathrm{f}}}=\quad$ terms of current US dollar). The data come from the official site of the International Financial Statistic of IMF;

Output differential is the difference between real GDP of Indonesia and foreign countries (in

$\mathrm{y}_{\mathrm{t}}-\mathrm{y}_{\mathrm{t}}^{\mathrm{f}}=$ terms of current US dollar). The data come from the official site of the International Financial Statistic of IMF;

Nominal interest rate (in terms of percentage change). The data come from the official site of

$\mathrm{i}_{\mathrm{t}}-\mathrm{i}_{\mathrm{t}}^{\mathrm{f}}=\mathrm{OECD}$, except Singapore, both home and foreign countries, the data come from the official site of International Financial Statistic of IMF;

$\pi_{\mathrm{t}}-\pi_{\mathrm{t}}^{\mathrm{f}}=$ Consumer price index. The data come from the official site of the International Financial

$\pi_{\mathrm{t}}=$ Statistic of IMF; and

$\mathrm{TB}=$ Export and import differential between Indonesia and foreign countries (in terms of current US dollar). The data come from the official site of Indonesian Statistical Bureau

\section{References}

Abhyankar, Abhay, Lucio Sarno, and Giorgio Valente. 2005. Exchange Rates and Fundamentals: Evidence on the Economic Value of Predictability. Journal of International Economics 66: 325-48. [CrossRef]

AbuDalu, Abdalrahman, and Elsadig Musa Ahmed. 2014. The Determinants of ASEAN-5 Real Effective Exchange Rate Vis-á-Vis the UK Pound. World Journal of Entrepreneurship, Management and Sustainable Development 10: 98-118. [CrossRef]

Bahmani-Oskooee, Mohsen, and Hadise Fariditavana. 2015. Nonlinear ARDL approach, asymmetric effects and the j-curve. Journal of Economic Studies 42: 519-30. [CrossRef] 
Bahmani-Oskooee, Mohsen, Amr Hosny, and N. Kundan Kishor. 2015. The Exchange rate disconnect puzzle revisited: The exchange rate puzzle. International Journal of Finance $\mathcal{E}$ Economics 20: 126-37. [CrossRef]

Bahmani-Oskooee, Mohsen, and Sujata Saha. 2017. Nonlinear autoregressive distributed lag approach and bilateral j-curve: India versus her trading partners: India's trade and J-curve. Contemporary Economic Policy 35: 472-83. [CrossRef]

Berman, Nicolas, Philippe Martin, and Thierry Mayer. 2012. How Do Different Exporters React to Exchange Rate Changes? The Quarterly Journal of Economics 127: 437-92. [CrossRef]

Bilson, John F. O. 1978. The Monetary Approach to the Exchange Rate: Some Empirical Evidence. Staff PapersInternational Monetary Fund 25: 48-75. [CrossRef]

Bouraoui, Taoufik, and Archavin Phisuthtiwatcharavong. 2015. On the Determinants of the THB/USD Exchange Rate. Procedia Economics and Finance 30: 137-45. [CrossRef]

Charles, Amélie, and Olivier Darné. 2009. Testing for random walk behavior in euro exchange rates. Économie internationale 3: 24-45.

Chowdhury, Abdur R. 1993. Does Exchange Rate Volatility Depress Trade Flows? Evidence from Error- Correction Models. The Review of Economics and Statistics 75: 700. [CrossRef]

Cushman, David O. 2000. The Failure of the Monetary Exchange Rate Model for the Canadian-U.S. Dollar. Canadian Journal of Economics 33: 591-603. [CrossRef]

Dekle, Robert, Hyeok Jeong, and Heajin Ryoo. 2005. A Re-Examination of the Exchange Rate Disconnect Puzzle: Evidence from Japanese Firm Level Data. SSRN Electronic Journal. [CrossRef]

Devereux, Michael B., and Charles Engel. 2002. Exchange Rate Pass-through, Exchange Rate Volatility, and Exchange Rate Disconnect. Journal of Monetary Economics 49: 913-40. [CrossRef]

Dickey, David A., and Wayne A. Fuller. 1979. Distribution of the Estimators for Autoregressive Time Series with a Unit Root. Journal of the American Statistical Association 74: 427-31. [CrossRef]

Dornbusch, R. 1976. Expectations and Exchange Rate Dynamics. The Journal of Political Economy 84: 1161-76. [CrossRef]

Engel, Charles, and Kenneth D. West. 2005. Exchange Rates and Fundamentals. Journal of Political Economy 113: 485-517. [CrossRef]

Evans, Martin D. D., and Richard K. Lyons. 2005. Meese-RogoffRedux: Micro-Based Exchange-Rate Forecasting. Financial Economics 95: 10.

Fitzgerald, Doireann. 2004. A Gravity View of Exchange Rate Disconnect. SSRN Electronic Journal. [CrossRef]

Frankel, Jefrey A. 1979. On The Mark: A Theory of Floating Exchange Rate Based on The Real Interest Rate Differential. American Economic Review 69: 610-22.

Frenkel, Jacob A. 1976. A Monetary Approach to the Exchange Rate: Doctrinal Aspects and Empirical Evidence. The Scandinavian Journal of Economics 78: 200. [CrossRef]

Gente, Karine, and Miguel A. Leon-Ledesma. 2006. Does the World Real Interest Rate Affect the Real Exchange Rate? The South East Asian Experience. The Journal of International Trade E Economic Development: An International and Comparative Review 15: 441-67. [CrossRef]

Hooper, Peter, and John Morton. 1982. Fluctuations in the Dollar: A Model of Nominal and Real Exchange Rate Determination. Journal of International Money and Finance 1: 39-56. [CrossRef]

Kwiatkowski, Denis, Peter C. B. Phillips, Peter Schmidt, and Yongcheol Shin. 1992. Testing the Null Hypothesis of Stationarity against the Alternative of a Unit Root. Journal of Econometrics 54: 159-78. [CrossRef]

Laganà, Gianluca, and Pasquale M. Sgro. 2007. The Exchange Rate Disconnect Puzzle: A Resolution? Asia-Pacific Journal of Accounting $\mathcal{E}$ Economics 14: 43-68. [CrossRef]

Lee, Junsoo, and Mark C. Strazicich. 2001. Break Point Estimation and Spurious Rejections with Endogenous Unit Root Tests. Oxford Bulletin of Economics and Statistics 63: 535-58. [CrossRef]

Lee, Junsoo, and Mark C. Strazicich. 2003. Minimum Lagrange Multiplier Unit Root Test with Two Structural Breaks. The Review of Economics and Statistics 85: 1082-89. [CrossRef]

Lee-Lee, Chong, and Tan Hui-Boon. 2007. Macroeconomic Factors of Exchange Rate Volatility Evidence from Four Neighbouring ASEAN Economies. Studies in Economics and Finance 24: 266-85. [CrossRef]

Meese, Richard A., and Kenneth Rogoff. 1983. Empirical Exchange Rate Models of the Seventies. Do They Fit out of Sample? Journal of International Economics 14: 3-24. [CrossRef]

Obstfeld, Maurice, and Kenneth Rogoff. 2001. The six major puzzles in international macroeconomics: is there common cause? NBER Macroeconomics Annual 15: 339-90. [CrossRef] 
Ouyang, Alice Y., and Ramkishen S. Rajan. 2016. Does Inflation Targeting in Asia Reduce Exchange Rate Volatility? International Economic Journal 30: 294-311. [CrossRef]

Panopoulou, Ekaterini, and Nikitas Pittis. 2004. A Comparison of Autoregressive Distributed Lag and Dynamic OLS Cointegration Estimators in the Case of a Serially Correlated Cointegration Error. The Econometrics Journal 7: 585-617. [CrossRef]

Pesaran, M. Hashem, Yongcheol Shin, and Richard J. Smith. 2001. Bounds Testing Approaches to the Analysis of Level Relationships. Journal of Applied Econometrics 16: 289-326. [CrossRef]

Raza, Syed Ali, and Sahar Afshan. 2017. Determinants of Exchange Rate in Pakistan: Revisited with Structural Break Testing. Global Business Review 18: 1-24. [CrossRef]

Sarno, Lucio, and Maik Schmeling. 2014. Which Fundamentals Drive Exchange Rates? A Cross-Sectional Perspective. Journal of Money, Credit and Banking 46: 267-92. [CrossRef]

Shin, Yongcheol, Byungchul Yu, and Matthew Greenwood-Nimmo. 2011. Modelling Asymmetric Cointegration and Dynamic Multipliers in a Nonlinear ARDL Framework. SSRN Electronic Journal 61. [CrossRef]

Tawadros, George B. 2017. Revisiting the Exchange Rate Disconnect Puzzle. Applied Economics 49: $3645-68$. [CrossRef]

Turan, Taner, and Mesut Karakas. 2018. Asymmetries in Twin Deficit Hypothesis: Evidence from CEE Countries. Ekonomický Časopis 66: 580-97.

Umit, A. Oznur. 2016. Stationarity of Real Exchange Rates in the 'Fragile Five': Analysis with Structural Breaks. International Journal of Economics and Finance 8: 254. [CrossRef]

(C) 2019 by the authors. Licensee MDPI, Basel, Switzerland. This article is an open access article distributed under the terms and conditions of the Creative Commons Attribution (CC BY) license (http://creativecommons.org/licenses/by/4.0/). 